\title{
The Effects of the change in Telecommunication Regulation on Incentive for Network Investment and Innovation - Based on Korean Telecommunications Regulation Changes-
}

\author{
Choong Young Jung ${ }^{*}$, Song Min Jung ${ }^{* *}$
}

Published Online Date: November 1, 2012

\begin{abstract}
This paper analyzes the impact of the change in telecommunication regulation changes including the unification of telecommunication service on network investment. The unification of telecommunication service plays a role of separating behavior regulation from entrance regulation and reducing entrance constraints. Therefore, it is expected that the market spillover effect is high through the improvement of behavior regulation. In addition, the effects of the other regulation changes in the 2010 Telecommunications Business Act revision are analyzed. This paper discusses critical factors affecting the decision making process in respect to the firm level and analyzes the impact path guiding investment and innovation. The key findings are as follows. First, the impact of entrance deregulation depends on the intensity of deregulation. If the intensity is not high, this regulation increases the incentive on investment and innovation. However, if the intensity is high as shown in abolishing of licensing, it affects the incentive negatively.

Second, if interconnection regulation focuses on existing facilities or the intensity is not strong, this light handed regulation might increase investment and innovation. However, if interconnection obligation is expanded to the facility not constructed or the facility applying new technology, this regulation might deteriorate investment.

Third, price deregulation increases the competition of service but it also increases the business opportunity, which means positive effect on investment. Finally, the paper proposes the guideline for telecommunications policy.
\end{abstract}

Keywords Telecommunication service unification, price regulation, interconnection regulation, investment innovation

\footnotetext{
* Department of Business Administration, Hannam University, Daejeon, Korea (cyjung@ hnu.kr)

** Department of Business Administration, Hannam University, Deajeon, Korea (Barbie 1233@nate.com)
} 


\section{Introduction}

This paper discusses the impact of different aspects of telecommunications regulation and the impact they have in terms of network investments and innovation. Especially, the network investment and innovation is important to the entrant and incumbent under entrant deregulation and horizontal regulation. Under this deregulation, the incumbent will have an incentive to reduce the investment innovation on a new network and the entrant will not have a risk of investing on the network facility. Many countries are reconsidering current policies to support investment and innovation in advanced networks and service. In the past, this policy was widely used through the world, but it has decreased with the privatization of public firms. Some countries including the United States of America have relied on the market without regulation. However, other countries like Korea, Japan, and Northern Europe continue to use these policies together with privatization. ${ }^{1}$ Also, more countries recognize the necessity of regulation on inducing the construction of a national broadband network.

However, by the revision of the Telecommunication Business Act in 2010, the rigid partition of telecommunications service in Korea became loosened and entrance regulation was largely relaxed. Therefore, the licensed telecommunication operator can provide all the network service without interference. We call this the unification of telecommunications service. At the same time, by the revised Act, the entrant can purchase wholesale service at retail minus price from facility based business providers and resell the service (such as MVNO).

By the revised Telecommunications Business Act in 2010, the entrants can select one of the following options for their business.

1) The construction of own facility

2) The purchase of whole sale service or elements (or resale)

3) The lease of telecommunications facilities

The entrant will select the option that gives highest NPV. It is known that the entrants will purchase or lease the service (including facilities) rather than construct their own facilities at the initial stage. However, it is necessary to consider that the construction or investment of new facilities can be delayed although it is undesirable. In other words, the entrants have an option value to make an investment at their time or not by leasing facilities or reselling services and this option value has strong effects on investment or innovation

\footnotetext{
${ }^{1}$ Chung(2006), Ida (2006), Eskelinen, Frank, \& Hirvonen (2008)
} 
decision-making. (Without this option value, they would have made a decision to invest today) Given these challenges, regulation will have to carefully consider its implications for the investment and innovation decisions that shape the future development of the sector. Therefore it is interesting to investigate the effects of future regulation on investment and innovation.

This paper first analyzes the impact of telecommunication service regulation changes. Second, the basic analytic framework for the impact of regulatory changes on network investment and innovation is presented. In the meanwhile, the impact of regulatory devices on investment and innovation is investigated using this framework. Finally, we conclude and provide the policy implications.

\section{The Impact of Telecommunications Business Regulation in Korea}

In 2010, KCC (Korea Communications Commission) revised telecommunications acts. The most important change of regulation is the unification of telecommunications service. The concept of telecommunication service unification is that the inclusive license for network transport service is introduced for business, which means abolition of positive classifications. (For example, local, long distance, international, internet access service, etc.) This change is followed by technology development and innovation. The past telecommunication regulations about telecommunications providers could not handle these technology changes. The critical issue from this change is how individual regulations such as entrance regulation, interconnection regulation, facility provision regulation, and price regulation will be implemented through service unification. Because if the services are unified, the concept of service as a unit of regulation will disappear so it is very important to set the criteria and scope for application.

\section{Entrance Regulation}

By the unification of telecommunications service, first, the license for individual service (such as local telephone, international telephone, internet access service) is not allowed. Under this new rule, the extra procedure is not necessary to get the right to the individual service, if the network service is licensed. However, under the past rule, the ex anti certification was essential do begin business. Furthermore, by the telecommunication acts, the three detailed services provided in the enforcement rule is unified into one basic telecommunications service. 
Second, it lowers the entrance barriers and increases the flexibility of regulation. Third, it becomes more important to classify the telecommunications service business (at present, there are three types of business: basic telecommunications, resale, and value-added service) under the low entrance barrier. It is because the amendment of the actions related with global openness such as foreigner ownership restriction and fairness examination, that the approval of M\&A is inevitable. Therefore, it might be desirable to let in the entrant and innovative operator with convergence technology although the present classification is retained for the time being.

Fourth, in the future, it is necessary to transform the present license mechanism into general permission. To get a stable transition, the differentiation between the basic telecommunications operator and reseller should be weakened in terms of utilization agreements, accounting separation, interconnection, and facility provision.

\section{Interconnection Regulation}

In telecommunications, interconnection is the physical linking of a carrier's network with equipment or facilities not belonging to that network. One of the primary tools used by regulators to introduce competition in telecommunications markets has been to impose interconnection requirements on dominant carriers.

There are some complicated issues related with interconnection regulation when the telecommunications service is unified because the common carrier undergoes various types of forms in facility ownership as the telecommunication service provided is unified. For example, when a provider owning its facility enters into internet service markets with the right of network transport service, it can also provide the long distance service or local service without essential facilities. In this case, it is disputable whether the interconnection regulation rule can be applied to this network transport service provider, along with being a service based business provider, and long distance provider.

Under the revised Acts, there is no difference between the basic telecommunications provider and reseller regarding interconnection conditions except interconnection charges. Therefore, it is necessary to set the new rule for interconnection charging under the unification system of service.

The regulation change such as unification of telecommunication service provided reflects all future IP network environments. Therefore, in the future, interconnection regulation should accommodate the innovation of all IP network and technology developments that follows the general regulation principle considering both innovation incentives and fair competition. To implement this principle, it is necessary to investigate the present inter- 
connection rule and the characteristics of all IP networks. Table 1 compares the major considering factors among PSTN, IP, and all IP networks.

Table 1 The major considering factors of interconnection

\begin{tabular}{|c|c|c|c|}
\hline Factors & PSTN & IP & All-IP \\
\hline $\begin{array}{l}\text { compulsory access } \\
\text { provider }\end{array}$ & dominant provider & $x$ & \\
\hline $\begin{array}{l}\text { nondiscrimination } \\
\text { access provision }\end{array}$ & dominant provider & $x$ & \\
\hline bottleneck facility & subscriber loop & full routing table & each layer \\
\hline QoS & guarantee & $\begin{array}{l}\text { retail: } \times \\
\text { wholesale: } \\
\text { SLA(transit) }\end{array}$ & each layer \\
\hline $\begin{array}{l}\text { access charging } \\
\text { criteria }\end{array}$ & cost & value & hybrid \\
\hline $\begin{array}{l}\text { settlement of access } \\
\text { charge }\end{array}$ & CPNP or B\&K & B\&K or ASP & B\&K or ASP \\
\hline $\begin{array}{l}\text { access charge } \\
\text { structure }\end{array}$ & usage & capacity-based, flat & Hybrid, 3 tiered \\
\hline retail rate structure & usage & flat & Hybrid, 3 tiered \\
\hline
\end{tabular}

CPNP: Calling Party Network Pay; B\&K: Bill and Keep; ASP: Access Seeker Pay

Table 2-1 The regulation of facilities provision

\begin{tabular}{|c|c|c|c|c|}
\hline & requested carrier & requesting carrier & facility & price \\
\hline & $\begin{array}{l}\text { - Facility based } \\
\text { provider owning } \\
\text { essential facility } \\
\text { - Facility management }\end{array}$ & & $\begin{array}{l}\text { Conduit, } \\
\text { pole, cable, } \\
\text { Collocation }\end{array}$ & Cost oriented \\
\hline $\begin{array}{l}\text { Facility } \\
\text { provision }\end{array}$ & $\begin{array}{l}\text { facilities such as } \\
\text { conduct, pole } \\
\text { - Facility based } \\
\text { provider and Facility } \\
\text { management agency } \\
\text { getting market size } \\
\text { and market share of } \\
\text { facility based service } \\
\text { and the criteria } \\
\text { specified by the } \\
\text { President Decree. } \\
{ }^{*} \text { Act article } 35^{-2}\end{array}$ & $\begin{array}{l}\text { Telecommunication } \\
\text { s service provider } \\
{ }^{*} \text { Act article } 35^{-1}\end{array}$ & $\begin{array}{l}\text { Leased line } \\
\text { (standard } \\
\text { contract) }\end{array}$ & $\begin{array}{l}\text {-local: } \\
\text { agreement } 100 \% \\
\text {-long distance/ } \\
\text { international: } \\
\text { 50\% discount }\end{array}$ \\
\hline
\end{tabular}




\section{Facility Provision}

Under the Telecommunications Business Act, a common carrier may, upon receipt of a request for the provision of telecommunications facilities from other common carriers, provide its telecommunications facilities by concluding an agreement. Summary of the requested carrier, requesting carrier, facilities provided, and the price, is shown on Table 1.

By the revised Telecommunications Business Act, the corresponding carrier is expanded to a telecommunications carrier from facility based business providers to reduce the gap between facility based business providers and service based business providers. It is important to set the criteria to determine the levels to apply for service based business providers. The extent of facilities owned or market share based on sales might be considered.

It is also necessary to consider the scope of requesting carriers if the gap between facilities based business providers and service based business providers is removed.

Table 2-2 The regulation of facilities provision

\begin{tabular}{|c|c|c|c|c|c|}
\hline \multirow{3}{*}{ LLU } & $\begin{array}{l}\text { Full } \\
\text { unbund } \\
\text { ling }\end{array}$ & $\begin{array}{l}\text { - facility based business } \\
\text { provider } \\
{ }^{*} \text { Act article } 36 \\
\text {-local carrier } \\
\text { possessing a local loop } \\
{ }^{*} \text { Guideline article 6-1 }\end{array}$ & $\begin{array}{l}\text { local carrier } \\
{ }^{*} \text { Guideline article 6-2 }\end{array}$ & $\begin{array}{l}\text { Full copper } \\
\text { local loop }\end{array}$ & $\begin{array}{l}\text { Cost } \\
\text { oriented }\end{array}$ \\
\hline & $\begin{array}{l}\text { Line } \\
\text { sharing }\end{array}$ & $\begin{array}{l}\text { - facility based business } \\
\text { provider } \\
{ }^{*} \text { Act article } 36 \\
\text {-local carrier } \\
\text { possessing a local loop } \\
{ }^{*} \text { Guideline article 11-1 }\end{array}$ & $\begin{array}{l}\text { Broadband internet } \\
\text { access provider with } \\
\text { leased line lease license } \\
{ }^{*} \text { Guideline article } 11-2\end{array}$ & $\begin{array}{l}\text { High } \\
\text { frequency } \\
\text { band of local } \\
\text { loop }\end{array}$ & $\begin{array}{l}\text { Cost } \\
\text { oriented }\end{array}$ \\
\hline & $\begin{array}{l}\text { Bit } \\
\text { stream } \\
\text { access }\end{array}$ & $\begin{array}{l}\text {-facility based business } \\
\text { provider with at least } \\
\text { 5oo,ooo broadband } \\
\text { internet subscribers } \\
\text { *Guideline article 16-1 }\end{array}$ & $\begin{array}{l}\text { Broadband internet } \\
\text { access provider } \\
\text { * Guideline article 16-2 }\end{array}$ & DSLAM, ATM & $\begin{array}{l}90 \% \text { of retail } \\
\text { price(exclud } \\
\text { ing contents } \\
\text { fee) }\end{array}$ \\
\hline
\end{tabular}

\section{Retail Price Regulation}

The regulation of current retail price is shown in Table 3. 
Table 3 The regulation of retail price

\begin{tabular}{|l|l|l|}
\hline $\begin{array}{c}\text { standard } \\
\text { contract }\end{array}$ & \multicolumn{1}{|c|}{ report } & \multicolumn{1}{c|}{ authorization } \\
\hline object & Facility based business provider & $\begin{array}{l}\text { Facility based business provider } \\
\text { specified for Authorization }\end{array}$ \\
\hline article & $\begin{array}{l}\text {-Act article 28(report of standard } \\
\text { contract, etc.) } \\
\text { - The facilities-based business } \\
\text { operator shall determine } \\
\text { telecommunications fees and } \\
\text { other terms for use according to } \\
\text { each licensed telecommunications } \\
\text { service to be provided and report } \\
\text { them (inclusive of the report of } \\
\text { change) }\end{array}$ & $\begin{array}{l}\text {-Act article 28(report of standard } \\
\text { contract, etc.) } \\
\text { - facility based telecommunication } \\
\text { service provided by facility based } \\
\text { business provider whose market size } \\
\text { and market share correspond to the } \\
\text { criteria set by the president decree } \\
\bullet \text { Act enforcement rule article 19-2 } \\
\text { (authorization of standard contract) } \\
\text { - service provided by facility based } \\
\text { business provider with the biggest } \\
\text { market share based on previous sales. }\end{array}$ \\
\hline
\end{tabular}

Comparing the revised Act with the previous Act in regard to price authorization, we can summarize as follows.

Table 4 The change in price regulation since the act revision

\begin{tabular}{|c|l|l|l|l|}
\hline \multirow{2}{*}{ service } & \multicolumn{2}{|c|}{ Report } & \multicolumn{2}{c|}{ Authorization } \\
\cline { 2 - 5 } & Before revision & After revision & \multicolumn{1}{c|}{ Before revision } & \multicolumn{1}{c|}{ After revision } \\
\hline tions & pelemmunica & $\begin{array}{l}\text { Telecommunica } \\
\text { tions }\end{array}$ & $\begin{array}{l}\text { Telecommunicatio } \\
\text { ns service notified } \\
\text { by MIC }\end{array}$ & $\begin{array}{l}\text { Telecommunication } \\
\text { s service notified by } \\
\text { KCC }\end{array}$ \\
\hline $\begin{array}{l}\text { Facility based } \\
\text { business }\end{array}$ & $\begin{array}{l}\text { Facility based } \\
\text { business }\end{array}$ & $\begin{array}{l}\text { The provider } \\
\text { specified based on } \\
\text { each licensed } \\
\text { service }\end{array}$ & $\begin{array}{l}\text { The provider } \\
\text { specified based on } \\
\text { each service } \\
\text { provided }\end{array}$ \\
\hline
\end{tabular}

From Table 4, we can see that the facility based business provider should still report its standard contract. That is, the service based business provider does not have an obligation to report its contract. Therefore, it is necessary to let even service based business providers have the same obligation about reporting the contract.

Since licensed telecommunications service as a regulation unit is changed to telecommunications service provided, the market dominant provider is specified in terms of service provided, not licensed service. The future argument is about the method of specifying a market dominant provider. It is 
needed to discuss whether to follow the existent detail licensed service or to specify the dominant provider through demarcation of related markets.

The future direction of rate regulation is deregulation. After evaluating the level of market competition, it is needed to loosen the authorization.

\section{The Impact of Regulation Change on Network Investment and Innovation}

\section{The Basic Model for Analysis of Impact of Regulation Change}

The present paper introduces the "real" options literature of Trigeorgis (1996) and Dixit and Pindyck (1995). In addition, we employ technology and innovation research of Kamien \& Schwartz (1982) and Sutton (1998). The regulatory change affects the traditional NPV and the option value directly and affects competition intensity and business opportunity indirectly.

\subsection{The Entrant Innovation Decision Problem}

We consider two types of telecommunications providers. One type is an incumbent that produces retail telecom services, resale services at wholesale prices, interconnection, and facilities provision. The other type is a new entrant (competitive telecommunication business provider) that produces retail telecom services and has a menu of choices that entail different amount of investment risk: from resale services without investment commitment to selfprovision with significant investment commitment. The entrant can handle network investment risk by utilizing the mix of resale, facilities provision, and self-provision.

The entrant must decide whether to (1) resell services; (2) lease facilities; (3) construct own facilities. Each alternative derives costs as well as revenues, and the entrant would select the alternative with the greatest net present value (NPV). We assume that reselling service or leasing facilities permit entrants to avoid entirely the necessity of making irreversible investments. Entrants can enter the market while waiting (not participating in R\&D) for the new technology to appear. We consider that alternative (3) increases network investment and innovation activities and alternatives (1) and (2) decrease innovation.

In terms of options theory, the self-provisioning alternative (3) forces the entrant to terminate an option on tomorrow's technology. Therefore the entrant must consider the value of a call option on a future technology as well as traditional NPV that might be decreased by waiting on new technology not investing into today. Both traditional NPV and option value are affected by 
regulation characteristics related with cost and conditions of alternative selection.

We can summarize these relations between the variables as follows.

- First, the regulation changes affect the traditional NPV and option value of alternative selection.

- Second, the regulation change affects competition intensity and business opportunity.

- Third, the completion intensity affects NPV through revenue change and option value.

- Fourth, business opportunity affects NPV through revenue change.

The first represents the direct effect of regulation change (Figure 1) and the other relations represent the indirect effect (Figure 2) through competition and business opportunity.

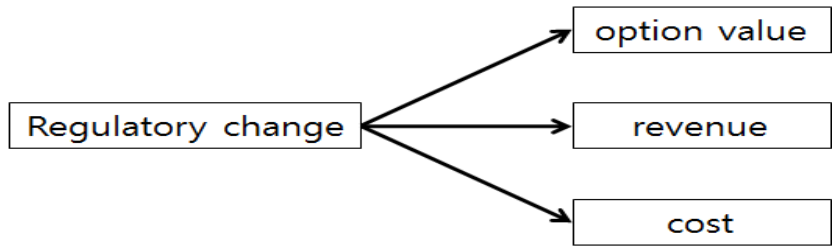

Figure 1 Direct impacts of regulatory changes

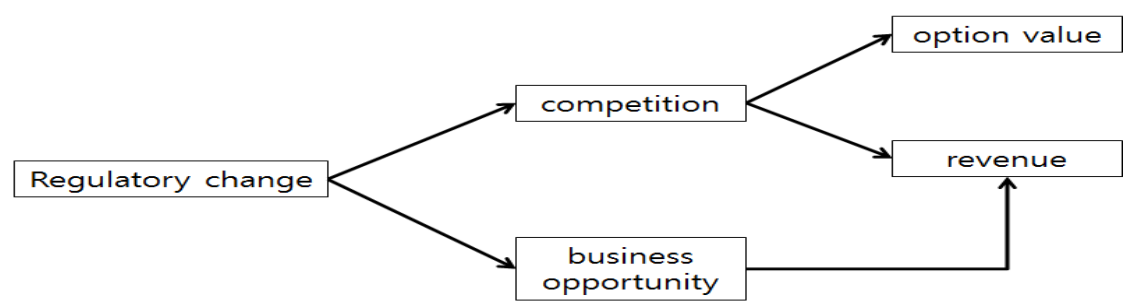

Figure 2 Indirect impacts of regulatory changes

\subsection{The Incumbent Innovation Decision Problem}

Before considering the entrant's investment decision, however, it is necessary to investigate the incumbent's decision given the regulatory requirements of the revised Act. The incumbent faces similar decisions and tradeoffs with the entrant. The incumbent must make additional investment decisions to reinforce existing plants or replace it with new technology. To some extent, the parameters affecting the incumbent's decision is the same as those affecting the entrant's decision: the incumbent must decide the opportunity cost of waiting to invest and estimate the risk that the value of the current technology will be replaced by new technology. 
However, the incumbent's tradeoffs are not identical to those faced by the entrant and so the incumbent has less option value for two reasons. First, the incumbent get less potential benefits of waiting than entrant because the incumbent already possesses network facilities and the best the incumbent will be able to do is use the network based on new technology into the existing network. Second, the incumbent has an obligation to provide resale service and bundle its network, while the entrant has no such obligation. Therefore, the incumbent does not have the opportunity to lease network facilities and this increases the cost of waiting and for the incentive of the incumbent to invest in today's technologies rather than waiting for tomorrows.

In addition to these incentive effects, the regulatory obligation may directly distort the incentive to invest in research and development of new technologies, depending on how the facilities provision and resale obligations are applied to the incumbent. If incumbent is enforced to provide not only the existing network but also the new network based on new technology at regulated rates, the incumbent's incentive to make $R \& D$ investments is reduced. The incumbent hopes that he can make some profits for some period of time after the innovation is proved successful. If regulators require that innovations be shared and offered at a regulated price, it is likely that the investments will be reduced or eliminated.

\subsection{Competition Intensity and Innovation}

Competitive intensity is also very important to investment and innovation. The intensity of competition and innovation is particularly important at NGN, which develops today's new technology. According to innovation research by Kamien \& Schwartz (1982) and Sutton (1998), competition does not always induce innovation and there is a non-linear relation between market power and innovation. The level of innovation increases as the competition intensity increases and then decreases after the competition intensity arrives at threshold. This means that the oligopoly rather than perfect competition or monopoly in industries with significant sunk costs, are seen as being the most helpful to investment and innovations. The regulatory policy can put the competitive intensity of the system into ranges where investment and innovation do not deteriorate.

\subsection{The Analytic Framework for Regulatory Impact on Network Investment and Innovation}

Regulatory policy instruments affect investment and innovation decisions of firms because they modify one or more of the factors in the investment. Some forms of regulation such as interconnection and facility provision obligation, are targeted to specific players (often those with market power) and hence exert differential effects on regulated and unregulated firms. To 
understand the impact of regulation change on the level and structure of investment, we use Bauer's (2010) analytic framework. However, our model is different from his study in several points. First, our study considers direct effect of regulatory change as well as indirect effect. Second, the present paper deals with entrance and license regulation, interconnection, and retail price regulation as well as network facility regulation. Bauer (2010) focused on only network regulation measures such as unbundling, open access, and network neutrality. Third, this paper considers Korean regulatory changes and applies our framework to Korean telecommunication regulation and innovation. Forth, our paper investigates interrelation between variables more clearly by considering incumbent and entrant's optimal investment decision. The entrant and incumbent's decision whether to invest today in facilities or provide services via resale service or facilities provision while waiting to invest will depend in part on the relative expected profitability of the different possibilities.

The last point helps us analyze impact paths of regulatory change on investment and innovation. Bauer (2010) does not consider the impact process about investment and innovation and so does not conjecture from which variable the impact is originated. Our study assumes three stages of impact process. The first is investment decision stage. The second is the direct impact of regulation change. The third is the indirect impact. To solve the optimal investment decision problem, first we solve the last stage impact linkage path. Then we solve second stage problem and finally investment decision, the first stage problem.

In the above section we explain the framework that will be adopted to analyze the impact path of different regulation measures on investment and innovation. In Section 2, the impact of entrance deregulation is analyzed and followed by interconnection and facilities provision in Section 3. This is followed by price regulation in Section 4 .

\section{Entrance Deregulation}

Entrance deregulation can be classified into the unification of licensed service, the easing of licensing conditions, and the abolishing of licensing.

\subsection{The Unification of Licensed Service}

In terms of the intensity in entrance deregulation, the unification of licensed service is very low and the abolishing of licensing is very high. We first investigate the indirect impact of completion and business opportunity on NPV and option value. The indirect impact path is shown by Figure 3. 


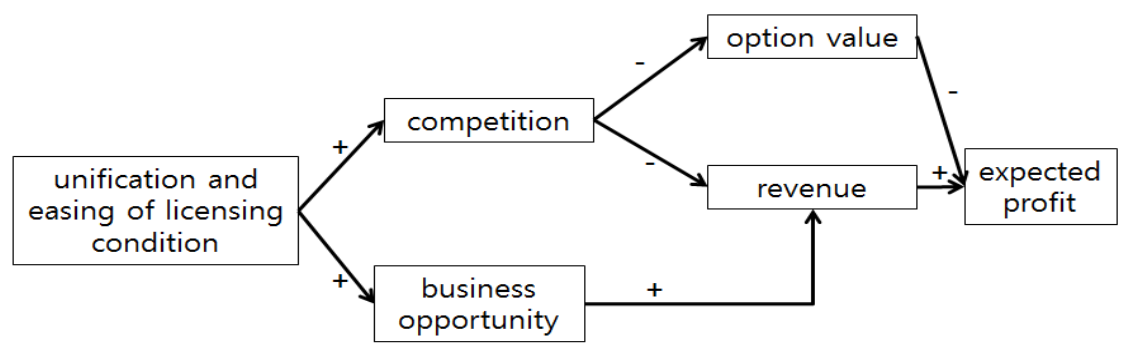

Figure 3 Indirect impacts of unification and easing of licensing

First, as an indirect impact, entrance deregulation can increase the competitive intensity by loosening the entrance constraint of facility based business providers. Specifically, the number of potential facility based service providers and new entrants is increased, which activates service competition. The unification of licensed service and the easing of licensing conditions can increase the competition adequately. The business opportunity is also increased for both incumbent and entrant. On the other hand, the competition decreases revenues and the adequate competitive intensity decreases the option value, which facilitates network investment as shown in the relation between competition intensity and innovation. The indirect impact path is shown by Figure 3.

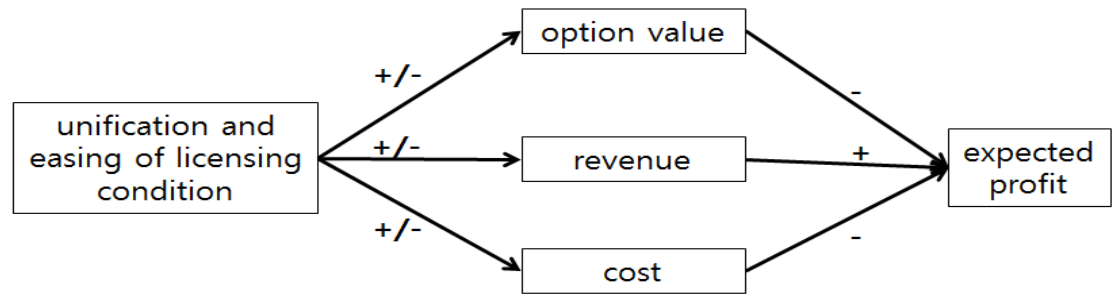

Figure 4 Direct impacts of unification and easing of licensing

Second, as a direct impact, the unification of licensed service and the easing of licensing conditions make little impact on revenue, cost, and option value directly. Finally, the incumbent and entrant can increase profit by increasing investment and innovation. Therefore, the unification of licensed service and the easing of licensing conditions might increase investment and innovation when we consider only indirect impacts.

\subsection{The Abolishing of Licensing}

First, as an indirect impact, the abolishing of licensing induces excessive competition and abundant business opportunity because the entrant can serve the market without constraint in network ownership, technological condition, 
and obligation. The excessive competition makes a positive effect on the option value because the providers have more alternatives for investment and innovation activities. However, excessive competition reduces the revenue of telecom providers. These are shown by Figure 5 .

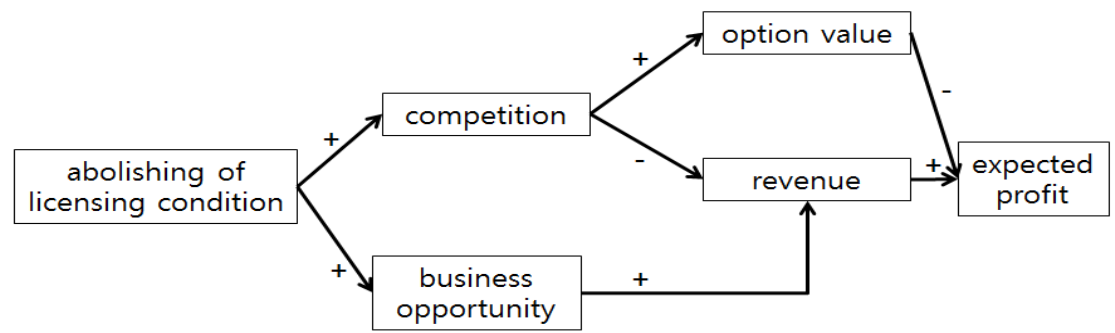

Figure 5 Indirect impacts of the abolishing of licensing

Second, as a direct impact, the abolishing of licensing gives both incumbent and entrants higher option value directly because the new facility based business provider can easily enter into market and there are many alternatives about network investment (including no investment in new technology and waiting) and innovation activities as shown by Figure 6 .

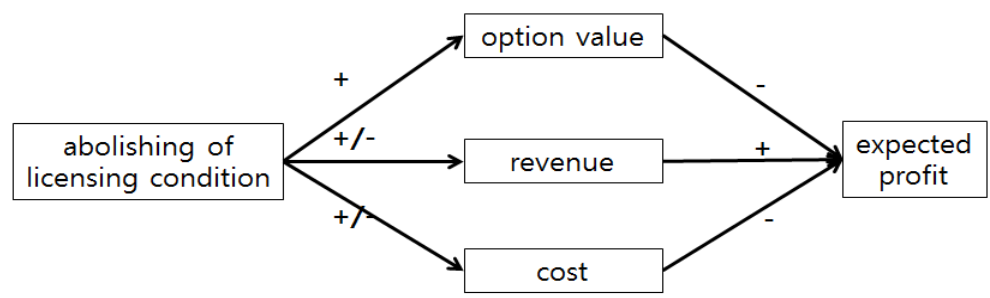

Figure 6 Direct impacts of the abolishing of licensing

Finally, the incumbent and entrant cannot increase expected profits by increasing investment and innovation as in Figure 7. Therefore, the regulation of abolishing of licensing might decrease investment and innovation.

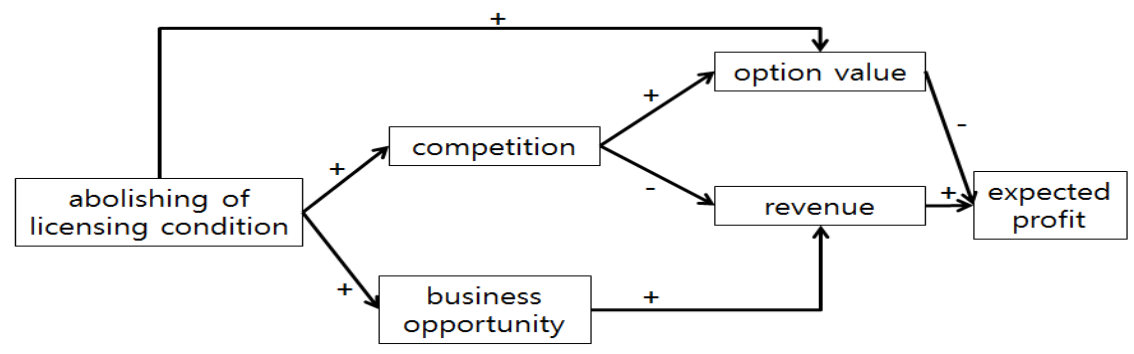

Figure 7 Total impacts of abolishing of licensing 


\section{Interconnection and Facility Provision}

The regulations of interconnection and facility provision such as rights of way, collocation, open access and unbundling affects the investment and innovation by touching the market structure and intensity of competition. This type of regulation is an important tool to not only benefit all market participants by providing seamless service but also foster fair competition between network providers. Also, this regulation reduces the transaction cost by standardizing major dealings between providers. For example, there is conduit, dark fiber access, collocation, full unbundling, and bit stream access for broadband network regulation. The problem is the strength of these regulations. The stringency is determined by the scope of regulation, negotiation procedures, and the price of interconnected facilities. For example, interconnection can be under the agreements between providers, or under the intervention of a regulator. It is also possible that enforcement forces handover of facilities to favour requesting provider.

The impact of interconnection on investment and investment is analyzed by the following framework. If $\mathrm{p}$ is access charge and $\mathrm{c}$ is the access cost, mark-up $\mathrm{m}=\frac{p-c}{c}$ can be used as indicator of stringency. If the markup is low or negative, this means that interconnection is stringent. The smaller the difference between the access charge and access cost, the smaller the entrant's initial cost. Generally, if interconnection regulation is strong, service based competition is greatly increased. Also, both incumbent and entrant have a high level of option value and therefore they have less incentive to invest in network construction. Furthermore, if this stringent regulation lasts for a long time, the incentive of investment and innovation will disappear.

The effect of interconnection regulation also depends on the characteristics of facilities invested by requested providers. If even the latest facilities with high risk and new technology are enforced to give access or provide for new entrant, both incumbent and entrant have high option values to postpone the construction of a new facility with innovative technology. This obligation will bring about negative effects on investment and innovation.

In the context of access charge and the facility requested, the interconnection regulation can be classified into two measures. One is light handed regulation that guarantees some mark-up and does not require giving compulsory access to new facilities with the latest technology. The other is light handed regulation where access charge is equal to cost and even new facilities are enforced to give access. 


\subsection{The Light Handed Regulation}

First, as an indirect impact, light handed regulation increases the intensity of competition adequately and business opportunity as seen in Figure 8. The adequate competition decreases revenues a little and the adequate competitive intensity decreases the option value, which facilitates network investment as shown in the relation between competition intensity and innovation.

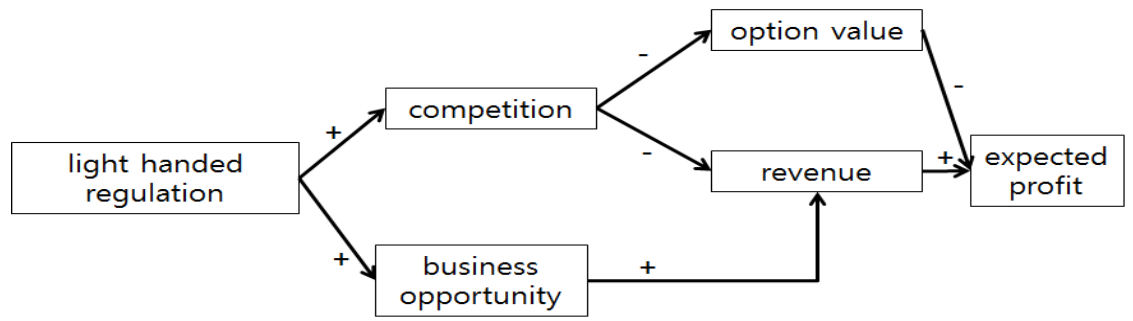

Figure 8 Indirect impacts of light handed regulation

Second, as a direct impact, this regulation also allows new options not to construct a new facility, which deteriorates investment and innovation as shown in Figure 9.

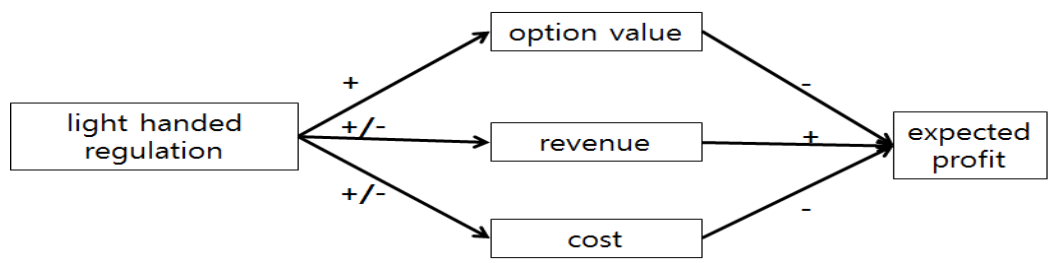

Figure 9 Direct impacts of light handed regulation

However, this option value is not enough to decrease expected profit. Finally, the incumbent and entrant can increase expected profits by increasing investment and innovation as in Figure 10.

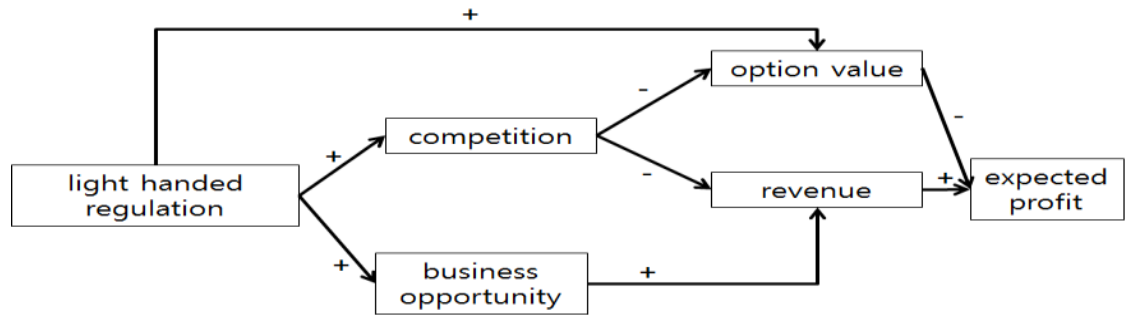

Figure 10 Total impacts of light handed regulation 
Therefore, this regulation might increase investment and innovation.

\subsection{The Heavy Handed Regulation}

First, as an indirect impact, heavy handed regulation increases the intensity of competition and business opportunity as seen in Figure 11. The excessive competition decreases revenues and the option value to get by not investing in network construction and waiting is increased as shown in section 1.3 (the relation between competition intensity and innovation).

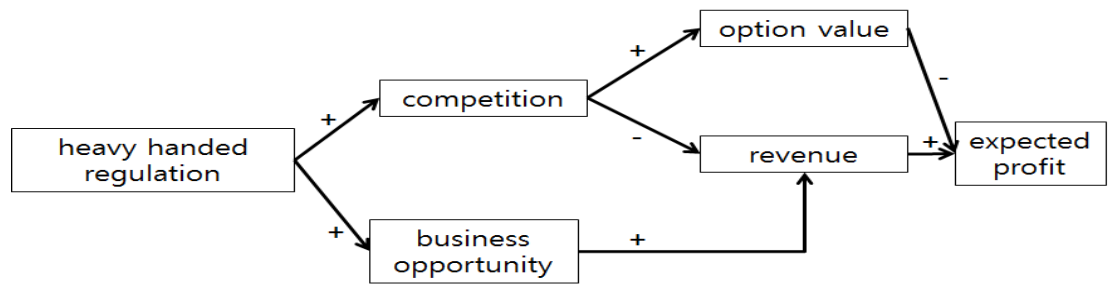

Figure 11 Indirect impacts of heavy handed regulation

Second, as a direct impact, this regulation also allows new options not to construct new facilities, which deteriorates investment and innovation as shown in Figure 12. This regulation also increases the entrant's opportunity cost when it participates in investment.

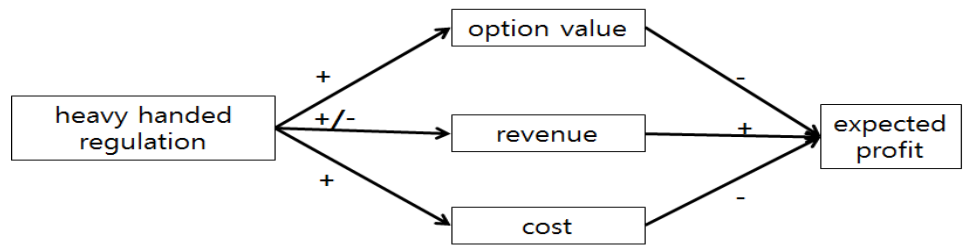

Figure 12 Direct impacts of heavy handed regulation

Finally, the incumbent and entrant cannot increase expected profits by increasing investment and innovation as in Figure 13.

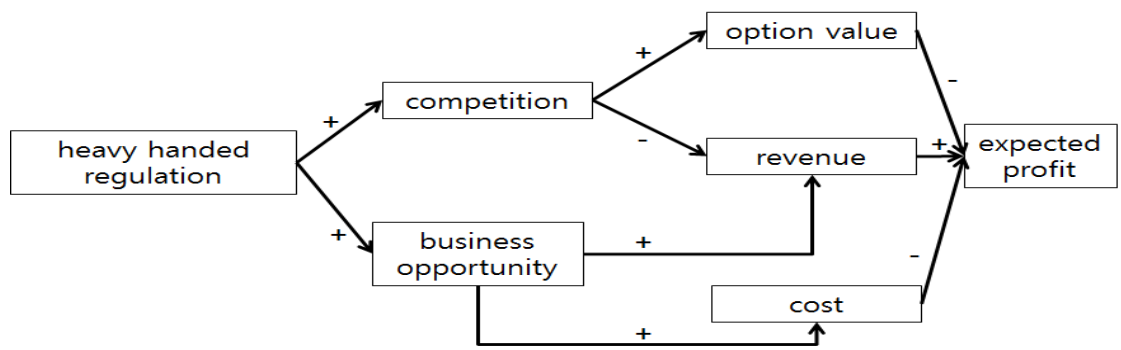

Figure 13 Total impacts of heavy handed regulation 
Therefore, this regulation definitely will deteriorate investment and innovation.

\section{Retail Price Deregulation}

First, as an indirect impact, as shown by Figure 14, retail price deregulation increases the competition in retail telecommunications service and increases the business opportunities because the flexibility of price the carriers can set is abundant. The competition decreases revenues and the option value to get by not investing in network construction and waiting is also decreased as shown in section 1.3. Even though the competition is activated and the revenue of the incumbent is reduced, the intensity of competition is too small and this loss is compensated by business opportunity.

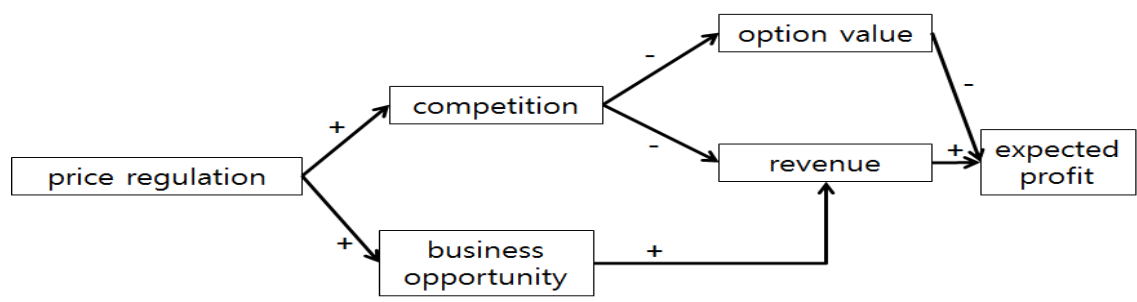

Figure 14 Indirect impacts of price regulation

Second, as a direct impact, this regulation increases revenue because the incumbent and entrant can design the price schedule freely as in Figure 15.

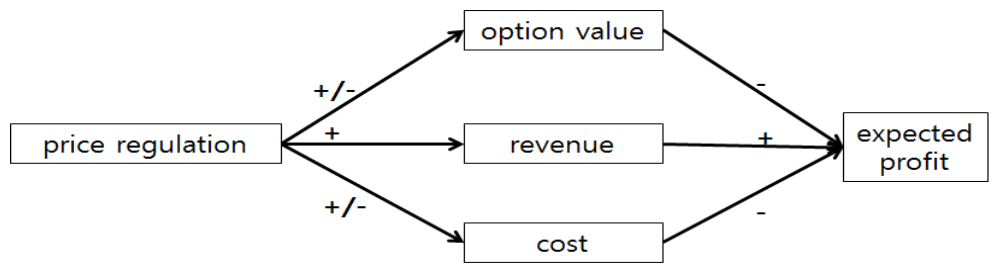

Figure 15 Direct impacts of price regulation 


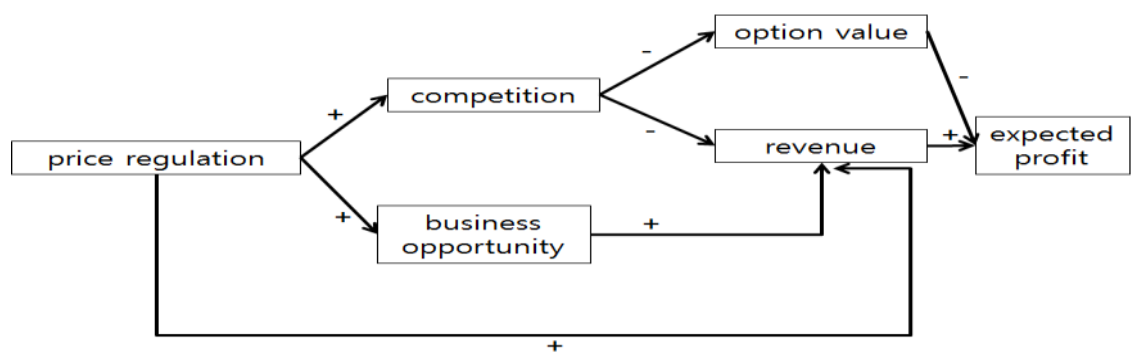

Figure 16 Total impacts of price regulation

Finally, the incumbent and entrant can increase expected profits by increasing investment and innovation as in Figure 16. Therefore investment and innovation is increased under price regulation.

\section{Summary and Discussions}

Summarizing the results so far, we get the following Table 5.

Table 5 Summary of the impacts on investment and innovation

\begin{tabular}{|c|l|c|c|c|c|c|c|}
\hline \multicolumn{2}{|c|}{} & $\begin{array}{c}\text { competitive } \\
\text { intensity }\end{array}$ & $\begin{array}{c}\text { business } \\
\text { opportunity }\end{array}$ & $\begin{array}{c}\text { option } \\
\text { value }\end{array}$ & revenue & cost & $\begin{array}{c}\text { expected } \\
\text { profit }\end{array}$ \\
\hline $\begin{array}{c}\text { Entrance } \\
\text { deregulation }\end{array}$ & $\begin{array}{l}\text { unification } \\
\text { licensing } \\
\text { conditions }\end{array}$ & + & + & + & & + \\
\hline $\begin{array}{l}\text { the abolishing } \\
\text { of licensing }\end{array}$ & + & + & + & & & - \\
\hline $\begin{array}{c}\text { Interconnection } \\
\text { and facility } \\
\text { provision }\end{array}$ & $\begin{array}{l}\text { light handed } \\
\text { regulation }\end{array}$ & + & + & + & & & + \\
\hline $\begin{array}{c}\text { Retail Price } \\
\text { regulation }\end{array}$ & & + & + & + & & + & - \\
\hline
\end{tabular}

First, we can see that the impact on investment and innovation depends on regulatory measures. Bauer (2010) used this type of analytic framework, but he focused on only one type of network regulation. We separate the regulation measures and add some other regulation such as retail price regulation where there are much disputes between Korean regulators and business providers.

Second, identical regulatory measures cause different results of impact on investment and innovation when the regulation intensity and detailed 
requirements are not the same. We explicitly noticed the option value and reviewed the implications for incumbents and entrants about investment decisions that were not addressed in previous studies.

Finally, the regulation changes impact the traditional NPV as well as option value through direct and indirect effect. If the intensity of entrance deregulation is not high, this regulation increases the incentive of investment and innovation. Also, if the intensity of interconnection regulation is not strong, investment and innovation is encouraged. Retail price deregulation makes positive effects on investment.

\section{Conclusions}

This paper investigated how facility based regulation will be changed through the revision of the Telecommunications Business Act. Also, based on these changes, we modelled for the impact path of regulatory measures on innovation and got the following results.

First, the impact of entrance deregulation depends on the intensity of deregulation. If the intensity is not high, this regulation increases the incentive of investment and innovation. However, if the intensity is high as shown in abolishing of licensing, it affects the incentive negatively.

Second, if interconnection regulation focuses on existing facilities or the intensity is not strong, this light handed regulation might increase investment and innovation. However, if interconnection obligation is expanded to the facility not yet constructed or the facility applying new technology, this regulation might deteriorate investment.

Third, price deregulation increases the competition of service but it also increases the business opportunity, which means positive effect on investment.

These results show that the impact of regulation change on innovation activities of telecommunications service providers should be taken into account to achieve optimal level of facility based competition in an era of next generation networks. However, for a more practical policy recommendation, it is necessary to try empirical mythology to analyze the inter relationship between variables. 


\section{References}

Alleman, J. and Noam, E. (eds.) (1999) The new investment theory of real options and its implications for telecommunications economics, Boston, Dordrecht, London: Kluwer.

Bauer, J.M. (2010) Regulation, public policy, and investment in communications infrastructure. Telecommunications Policy, 34, 65-79.

Brandenburger, A.M. and Nalebuff, B.J. (1996) Coopetition, New York: Currency Doubleday.

Chung, I. (2006) Broadband, the information society, and national systems: The Korean case, In M. Fransman (ed.), Global Broadband Battles: Why the US and Europe lag while Asia leads, Stanford, CA: Stanford University Press, 87-108.

De Bijl, P. and Peitz, M. (2008) Innovation, convergence and the role of regulation in the Netherlands and beyond, Telecommunications Policy, 32, 744-754.

Dixit, A. and Pindyck, R.S. (1995) The options approach to capital investment, Harvard Business Review, May-June, 105-115.

Elixmann, D., Dragan, I., Neumann, K.H., and Plückebaum, T. (2008) The economics of next-generation access. Bad Honnef, Germany: WIK-Consult.

Eskelinen, H., Frank, L., and Hirvonen, T. (2008) Does strategy matter? A comparison of broadband rollout policies in Finland and Sweden, Telecommunications Policy, $32,412-421$.

Farrell, J. and Weiser, P.J. (2003) Modularity, vertical integration, and open access policies: towards a convergence of antitrust and regulation in the internet age, Harvard Journal of Law and Technology, 17(1), 85-134

Fransman, M. (2007) The New ICT ecosystem: Implications for Europe, Edinburgh: Kokoro.

Gayle, P.G. and Weisman, D.L. (2007) Efficiency trade-offs in the design of competition policy for the telecommunications industry, Review of Network Economics, 6(3), 321-341.

Ida, T. (2006) Broadband, information society, and the national system in Japan, In Fransman, M. (ed.), Global broadband battles: Why the US and Europe lag while Asia leads, Stanford, CA: Stanford University Press, 64-86.

Pindyck, R.S. (2007) Mandatory unbundling and irreversible investment in telecom networks, Review of Network Economics, 6(3), 274-298.

Prieger, J.E. (2002) Regulation, innovation, and the introduction of new telecommunications services, Review of Economics and Statistics, 88(4), 704-715.

Reardon, M. (2009) The price of broadband, CNET News, Retrieved October 12, 2009 from http://news.cnet.com/8301-30686_3-10364590-266.html?tag=mncol.

Trigeorgis, L. (1996) Real options: managerial flexibility and strategy in resource allocation, MIT Press, Cambridge, Massachusetts. 